\title{
JUURNAL.RU
}

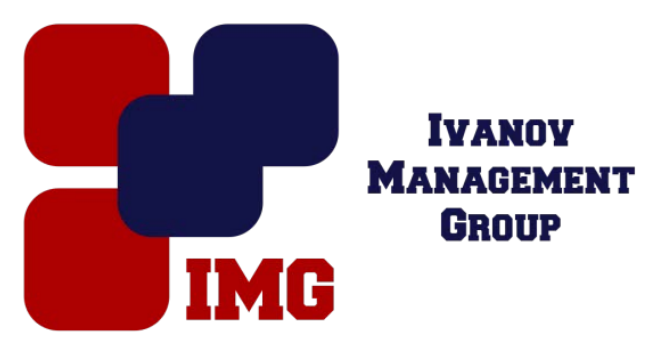

Семенова А.С. Московский технологический университет Москва, Россия

doi: 10.18411/lj-30-04-2017-2-16

idsp 000001:lj-30-04-2017-2-16

\section{Модифицированный термопластик для разметки дорожных покрытий}

В данной работе исследовалось влияние на текучесть термопластичной композиции, предназначенной для разметки дорог (термопластик), содержания в еe составе глицеринового эфира канифоли (ГЭК). Термопластик фирмы «СпецПласт» представляет собой полифракционный дисперсно-наполненный полимерный композиционный материал. Минеральный наполнители и пигмент имеет фракцию до 0,8 мкм. В соответствии с ГОСТ Р 52575-2006 текучесть подобных композиций должна быть более 5 г/с для обеспечения нормальной работы авторазметчика. Особенно важен этот показатель при работе на аэродромах, так как это сокращает время работ на взлетно-посадочных полосах.

Нами исследовались термопластичные композиции с различным содержанием ГЭК от (см. таблицу). Для оценки текучести использовали методику «Определение текучести термопластиков» ТУ 2253-001-499479982016. Текучесть расплава термопластика определяют с помощью металлической воронки с закрывающимся отверстием диаметром 10 мм, предварительно прогретой в термостате до $200{ }^{\circ} \mathrm{C}$. Расплав термопластика заливают в воронку с закрытым отверстием. Затем открывают его и фиксируют время вытекания расплава, которое должно происходить в течение 10 - 12 с. Вытекший расплав охлаждают и взвешивают. Текучесть $(\mathrm{T}, \mathrm{r} / \mathrm{c})$ рассчитывают по формуле: $T=$ $M / t$, где М - масса вытекшего расплава, г; $\mathrm{t}$ - время вытекания термопластика, с. За результат испытания принимают среднее арифметическое значение двух параллельных определений, допустимое расхождение между которыми не должно превышать 0,1 г. 
Таблицุа 1.

Влияние содержания смоль на текучесть термопластика

\begin{tabular}{|c|c|}
\hline Содержание ГЭК, масс \% & Текучесть, г/с \\
\hline 12,00 & 4,20 \\
\hline 12,50 & 5,30 \\
\hline 13,00 & 5,68 \\
\hline 13,50 & 6,47 \\
\hline 14,00 & 7,20 \\
\hline 14,50 & 8,40 \\
\hline 15,00 & 8,94 \\
\hline
\end{tabular}

Оптимальным оказалось содержание ГЭК более 12,5 \%, (текучесть более 5 г/с). При увеличении содержания ГЭК выше 14,5 \% наблюдалось расслоение расплава. Для повышения водостойкости в композицию добавляли нефтеполимерную смолу (соотношение 3 к 7). Дальнейшие исследования показали, что по эксплуатационным характеристикам (яркости, водостойкости, износостойкости, адгезии к асфальту и др.) полученное покрытие соответствует предъявляемым ТУ 2253-001-49947998-2016 требованиям.

1. ТУ 2253-001-49947998-2016 «Определение текучести термопластиков»

2. ГОСТ Р 52575-2006 «Дороги автомобильные общего пользования». 